\title{
Comic revisions? Motherhood and women's comedy in contemporary Germany
}

\section{Katherine Stone}

To cite this article: Katherine Stone (2016) Comic revisions? Motherhood and women's comedy in contemporary Germany, Feminist Media Studies, 16:6, 1014-1028, DOI:

10.1080/14680777.2016.1178159

To link to this article: https://doi.org/10.1080/14680777.2016.1178159

Published online: 04 May 2016.

Submit your article to this journal $\pi$

Џll Article views: 287

Q View related articles ¿ત

View Crossmark data $[\pi$

7 Citing articles: 1 View citing articles 


\title{
Comic revisions? Motherhood and women's comedy in contemporary Germany
}

\author{
Katherine Stone \\ Department of German, Maynooth University, Maynooth, Co. Kildare, Ireland
}

\begin{abstract}
Maternal stereotypes and the realities of mothering are prominent themes in Anke Engelke's Ladykracher and Martina Hill's Knallerfrauen, two of the most popular sketch shows in twenty-first-century Germany. This article relates their success to social anxieties about motherhood, which Engelke and Hill illuminate through the theme of their sketches as well as through their very use of comedy to do so. I begin by using close-readings of Ladykracher and Knallerfrauen to illuminate the political potential of the sketch form to challenge maternal myths and articulate taboo feelings such as maternal ambivalence. I then consider the innovation of these maternal sketches in view of traditional theories of comedy, which paradoxically draw their imagery from the realm of the maternal even though they discount real women and mothers as comic agents. I argue that the maternal sketches of Engelke and Hill are thus doubly subversive, challenging maternal taboos as well as the discursive and generic norms they sustain.
\end{abstract}

\section{ARTICLE HISTORY}

Received 4 May 2015

Revised 28 November 2015

Accepted 4 January 2016

\section{KEYWORDS}

Motherhood; sketch comedy; Germany; feminist comedy; new momism; ambivalence

\section{Introduction}

Motherhood has gained in prominence as a theme in German comedy since the turn of the century, thanks largely to the sketch shows Ladykracher ("Cracking Ladies," Sat1, 2001-2013) and Knallerfrauen ("Women with a Bang," Sat1, 2011-2014), star vehicles for Anke Engelke and Martina Hill respectively. ${ }^{1}$ Although Engelke and Hill are coy about their feminist intentions, their comedy revolves around "women's business" (or "Frauensache," a working title for Knallerfrauen). At their smartest, the sketches reveal through exaggeration the sheer tedium of traditionally feminine work, the absurdity of beauty rituals, and the deficiency of gender role expectations-especially motherhood.

Engelke and Hill are beneficiaries of the so-called "comedy boom" of the 1990s, which saw the proliferation of successful home-made comedy programmes in Germany (Gerlinde Schumacher and Daniela Hammer 2000). Engelke began her television comedy career in the mid-1990s as part of the ensemble cast for Die Wochenshow ("The Weekly Show," Sat1, 1996-2002), Germany's answer to Saturday Night Live. In 2001, Engelke then stepped into the limelight as the lead actress in Ladykracher, which ran intermittently until 2013. At its peak, Ladykracher was watched by 3.5 million viewers, receiving an above-average market 
share of 20 percent in the key marketing demographic of fourteen-forty-nine year olds (BRAINPOOL 2003). Engelke has received the German Comedy Prize for "Best Sketch Show" six times and the German Television Prize for "Best Comedy Programme" twice. She was nominated for an International Emmy in 2003. Martina Hill also began her sketch career in comedy ensembles such as the television parody show Switch Reloaded ("Switch Reloaded," ProSieben, 2007-2012) and in the news satire Heute-Show ("Today Show," ZDF, 2009-present). In 2011, she spread her comedic wings as a writer and front-woman for the sketch show Knallerfrauen, which garnered Hill both the German Comedy Prize and the German Television Prize for Comedy in 2012. At the height of its success, Knallerfrauen drew in almost three million viewers and received a 21.7 percent share of the market (Presseportal 2014). Both Knallerfrauen and Ladykracher were more successful in Germany than international prototypes such as Smack the Pony (1999-2003) and Vous les Femmes ("WOMEN!," 2007-2010), on which Knallerfrauen was initially based (Peer Schader 2012). This pattern of reception suggests that thematically and stylistically Engelke and Hill more effectively tapped into German cultural sentiments.

In addition to revitalizing the sketch genre, the German "comedy boom" eased the entry of female performers into the mainstream. As the variety of comedy programmes increased, so too did the range of themes being addressed (Karin Knop 2007, 1997). Today, the political satire, cabaret, and slapstick that defined the male-dominated German comedy scene in earlier decades is complemented by various formats that highlight the absurdity of the everyday, particularly in regard to sexual and gender relations (Helga Kotthoff 2004, 16). This thematic shift is reflected in the growing number of prominent television comediennes in Germany. Unlike their predecessors in theatrical cabaret and television variety, these women refuse to function solely as the object of or accessory to male humour (Kotthoff 2004, 16), with acts such as Hella von Sinnen, Maren Kroymann, Carolin Kebekus, and the Missfits Gerburg Jahnke and Stephanie Überall loudly proclaiming their feminist credentials.

The focus on mothers in Ladykracher and Knallerfrauen distinguishes Engelke and Hill from most of their predecessors and contemporaries. This thematic difference is in part a question of form. Their sketches are more realist than the stage-based, narrative work of other prominent comediennes. Filmed in natural settings, Engelke and Hill are thus able to exploit the humour of domestic occurrences, interactions, and feelings that evade narrative expression. In particular, their satirical sketches often coalesce around maternal characters that are reluctant, mean, or jaded, and therefore a far cry from the idealized mothers who populate the Western media. The German obsession with celebrity moms (from supermodel-turned-supermom Heidi Klum to three-time mother Engelke) is a local variant on a global media trend, what Susan Douglas and Meredith Michaels dub the ideology of "new momism" that has swelled since the 1980s (2004). This cult modernizes a regulatory myth proclaiming that motherhood is not merely woman's highest vocation but also the key to her personal happiness. As Douglas and Michaels $(2004,24)$ warn, however, that the "new mom" is the fetish of "a culture that praises mothers in rhetoric and reviles them in public policy."

Comedienne Carolin Kebekus applauds Anke Engelke for exposing the fissure between rhetoric and reality in her sketches about bad mothers (Michaela SchießI 2015). Kebekus explains that there is something liberating about Engelke's mother figures, whose bitterness is not simply absorbed by the gag. Their actions stand as a drastic reflection of a society that continues to imagine itself as family-friendly despite growing evidence to the contrary. Debates about children and motherhood are omnipresent in the political and media 
landscape of twenty-first century Germany, where the fertility rate has sunk well below the so-called maintenance level required to ensure a stable population (Valerie Heffernan 2014, 131). Concerns about the shrinking and ageing population intensified in the early years of the new millennium, with family politics becoming a central talking point in the Federal Election of 2005. In the discursive realm, numerous media pundits painted an apocalyptic picture of the impending "demographic time bomb" (Frankfurter Allgemeine Zeitung 2005). Frank Schirrmacher's Das Methusalem-Komplott (The Methuselah Complot, 2004), Udo di Fabio's, Die Kultur der Freiheit (The Culture of Freedom, 2005), and Eva Herman's Das EvaPrinzip (The Eva Principle, 2006) are but a few of the bestselling books that speculated on the sources and consequences of Germany's alleged demographic crisis.

Again and again, the nation's population problems have been cast in terms of a crisis of motherhood. A contribution by former television presenter Eva Herman typifies the wide-reaching conservative response. Herman connects the low birth rate to rising levels of female employment, arguing that the women's movement led women to suppress their natural femininity and deny their maternal vocation. Citing biological principles, Herman $(2006,80)$ encourages women to embrace their capacity to "build a warm nest, establish networks, and provide a shelter in a world that is becoming ever more ruthless." A number of commentators in Germany have identified such fraught rhetoric as the crux of Germany's demographic problem. For example, the scholars Steffen Kröhnert and Reiner Klingholz $(2008,22)$ explain the low desire for children in Germany with reference to a "collision" between maternal ideology and modern society. The dominant cultural conception of motherhood appears to be incompatible with emancipated living. Similarly, Günter Burkart (2006, 120-122) links the "culture of childlessness" in Germany to a "culture of doubt" resulting from high standards of good parenting-and especially good mothering. These commentators suspect that the low birth rate is a sign of women's rebellion against the cult of motherhood.

Engelke and Hill provide a comic counterforce to sacralising discourses about motherhood in Germany, revealing their emptiness and ideological function. Their success bears out Andy Medhurst's $(2007,112)$ claim that comedy tends to thrive "at flashpoints of cultural nervousness." I aim to show that the distinctive appeal of Ladykracher and Knallerfrauen relates to their expression of maternal taboos in a German cultural context in which motherhood is sanctified. In the course of this article, I suggest that Engelke and Hill tapped into an emerging "structure of feeling" about maternal culture. Raymond Williams $(1977,130)$ coined this term to describe the variable gap between prevailing ideologies and the social as it is lived by individuals. Often this tension is experienced as "an unease, a stress, a displacement, a latency."The ambivalent and blasé mothers depicted in Ladykracher and Knallerfrauen articulate the gap between maternal myths and real women's experiences in Germany. The innovation of these sketches lies not merely in their content, however, but precisely in the choice of comedy as their vehicle of expression. Engelke and Hill challenge enduring assumptions about maternity that underpin the Western comic tradition and conventional attempts to define its social status and political function. In the final section of this article, I show that the (masculine) comic tradition is suffused with the contradictory ideas about motherhood that permeate Western culture, in Germany and beyond. Motherhood is at once exalted and trivialized in debates about the gender of humour. The maternal sketches of Engelke and Hill are thus doubly subversive, challenging maternal taboos as well as the discursive norms they sustain. 


\section{Maternal sketches}

Often reliant on hyperbole, Anke Engelke's Ladykracher sketches exploit recognizable character types: the hypocrite, the dumb blonde, and the selfish wife, to name but a few. In the first episode of season eight, for example, we see a woman dunking her husband's head in the toilet bowl because he has used the hand towel to dry his genitals. She extracts an apology from him before hypocritically taking his razor to shave her pubic hair. This hypocrisy marks her figure out as somebody who has become set in her ways, estranged from what Henri Bergson (1921) refers to as the elasticity of life. According to Bergson, laughter identifies, mocks, and therefore punishes such rigidity. The play with gender stereotypes in Ladykracher fulfils a similar function. The unexpected violence of the wife, whether it provokes shock or laughter in the viewer, reveals the automatism of the spectator who relies on stereotypes to interpret the exposition of the sketch. It pushes the viewer to question the validity of his or her assumptions.

The play with stereotypes is cardinal to the humour of Ladykracher. Indeed, this title, linking women ("Lady") and firecrackers ("Kracher"), was chosen to convey the unexpected (Sat1 2011). Its surprises often appear in maternal form. In another sketch from the final series (season eight, episode two), a woman complains to two friends about the exertions of motherhood, which are exacerbated by the fact that her husband continues to work fulltime. When she gets up to use the bathroom, her male friend assures his partner that he would never leave her to bear the brunt of childcare. He would happily work part-time or even give up work completely. The humour of this sketch springs from the unanticipated reaction of his girlfriend, who accuses him of laziness. He responds with a hesitant reminder that "looking after children and a home are work too," merely inviting further scorn:

What's with all the naff emancipation drivel? Do you really think I want to listen to moaning clients all day ... work overtime, kiss my boss'arse, chase up colleagues ... while you sit at home playing coochy-coochy-coo? Anyway, you earn more as a man. You cannot seriously think that I want to give up my standard of living just so that you can embrace your weak feminine side?

This jibe sheds light on some of the obstacles facing families in contemporary Germany, from the timeworn devaluation of maternal work to the sort of cultural prejudices that might put fathers off making full use of their right to at least two months' parental leave. In this sketch, Engelke also makes a mockery of the assumption that a women's highest priority is motherhood. Here we have an example of what Judy Little $(1983,1)$ diagnoses as the "renegade" quality of comedy by women that "mocks the deepest possible norms," in this case the equation of womanhood with motherliness.

The Ladykracher sketches repeatedly subvert conventional expectations of mothers. In the very first episode, when a young girl makes a gift for her mother's birthday, Engelke's protagonist cannot conceal her disappointment:

You know that Mummy wanted a hands-free set. And what have you given Mummy? A handmade, wonky, deformed cardboard duck. I couldn't even get fifty cents for it at a flea market, never mind make a phone call with it. [...] Mummy is very disappointed.

Insensitive mothers are frequent stock figures of Engelke's comedy. Without emotion, they tell their daughters that the dog has been put down for being too friendly, for example, or that Daddy has left home and is not bothered about custody. In another sketch, mother and father explain that the tooth fairy was unable to leave money because Daddy accidentally shot her when she snuck into the house in the middle of the night. In each case, the comic 
trigger is the fact that the behaviour of these white, middle-class, good-looking parents is a far cry from the model of good parenting that they usually symbolize in the public imagination.

In one double-layered sketch from episode five of season eight, Engelke mocks both the deceptiveness of appearances and the absurdity of certain ideals of "good" parenting. As a social worker, Engelke investigates a family after reports of child neglect, expressly, of failing to provide for their son materialistically. After all, what child of the twenty-first century does not have a games' console or flat-screen television? This sketch neatly demonstrates the ambivalent subversiveness of satirical comedy in which the words and action often carry a "straight meaning" that reflects the dominant ideology, leaving "an excess of meaning [...] that is available for viewers to use to undercut the straight meaning" (John Fiske 2009, 72). In this case, the subtlety of the sketch at once trades on and exposes our assumption that material well-being equals psychological welfare.

Ladykracher reveals that German culture's investment in motherhood is not merely a rich source of comic incongruity. Toying with maternal myths may also generate comic insight. A shining example is a recurring mother figure that features in some of the monologues that separate the plot- or action-based sketches. In these monologues, Engelke takes on different stereotypes, presenting herself as though for the sort of video profile that appears on online dating websites - a device also used on Smack the Pony. This particular character is an affected member of the beau monde whose baby (born of a surrogate mother, of course) is simply another status symbol. She is an exaggerated embodiment of the "Turbo-Mutter," whom Susanne Lang (2005) describes as the German variant of the "new mom," the woman who manages her family as part of a wider post-modern project of self-realization encompassing career and personal style. Lang suspects that the proliferation of maternal role models in contemporary Germany reflects concerns over the low birth rate. The "Turbo-Mutter" is the perfect advertisement for a new phase of family politics inaugurated by a trio of family ministers (Renate Schmidt [2002-2005], Ursula von der Leyen [2005-2009], Kristina Schröder [2009-2013]) who fought for better provisions for working mothers and insisted on the lifestyle compatibility of motherhood. For as Elisabeth Beck-Gernsheim $(2001,120)$ has pointed out, greater risk and anxiety are attached to lifestyle choices today because of the seemingly endless options open to individuals. As a result, having children has ceased "to be a natural part of life."

According to Lang, the mass media has collaborated with neoliberal political forces to recalibrate this emotional climate. Glamorized maternal images speak to the potential mother as emotional being. These maternal "luminosities" particularly appeal to women's materialist impulses (Angela McRobbie 2013, 31). The 2011 launch of Brigitte-Mom, a quarterly spin-off of the popular women's magazine Brigitte, indicates the extent to which German motherhood has been re-conceptualized as a self-conscious consumer identity, embedded in global pop culture, as the American "Mom" in the title of this publication indicates. For Lang, such publications sell women on the idea that children belong "to a modern lifestyle" (a phrase she borrows from Renate Schmidt). Engelke's "Turbo-Mutter" monologues take this shibboleth literally, thereby emptying it of content. It is clear that her "Turbo-Mutter" is more interested in outside appearances than in actually mothering.

One of Engelke's most rebellious skits treats maternal ambivalence-about which our culture is itself deeply ambivalent if not wilfully ignorant. In the scene in question (series one, episode two), Engelke stands with a pram at the top of a set of stairs, trying to find 
somebody to help her get down. This scenario can be read as a metaphor for society's apathy about mothers' day-to-day struggles. After being repeatedly ignored, Engelke's protagonist snaps, screaming "excuse me" to attract the attention of bystanders before bursting into a ditty sung to the tune of Don McLean's "American Pie": "Bye, bye, good times are over now, no more boozing, shagging, dancing, only baby's blubbering. No more holidays, just pampers and fruit puree. Who gives a damn? So what? I'll be free again in eighteen years."The discord between the upbeat tune and the sentiment of the lyrics is a musical interpretation of the cheery façade that many women feel obliged to assume in order to conform to maternal norms. We should not underestimate the power of such sketches, which are perhaps the most visible outlet for maternal ambivalence in German culture. Rozsika Parker $(1997,17)$ suggests that humour is the only "safe" vehicle for the expression of maternal ambivalence because, no matter what taboos it breaks, any offence is discharged by the comic subterfuge, the insistence that no harm is intended. The licence for transgression built into the comic form further defuses any potential insult.

Engelke admittedly claims that her comedy has little political impetus: "I don't want to lecture people, and I don't want to allude to concrete ills, like a satirist would. I want to present the familiar from a new angle" (Katharina Wantoch 2015). For her, comedy is about the pleasure of exaggeration and excess rather than a vehicle for pursuing political goals. This philosophy is apparent in the monologues in which Engelke offers up feminine stereotypes for our amusement. She portrays the dumb blonde, the hopeless singleton, the Thai bride, and more complex but no less problematic figures such as the fat, grotesque woman unaware of her ugliness and the butch woman who seems not to notice that she embodies the clichés about queer sexuality that she discusses at length. Unlike the "Turbo-Mutter," these are the sort of marginal figures that have traditionally been the butt of a chauvinist comedy from which feminist humorists and critics have tried to distance themselves (Gail Finney 1994, 5-11). Unlike the plot-driven sketches of Ladykracher, which are funny because they invert the snap judgements that we make in response to orchestrated visual cues (such as the pretty, white mother), the monologues are meant to be funny because these women match our expectations, in their ways and appearance, and are unaware that they embody stereotypes. Their subversive potential is therefore limited.

The same cannot be said for the only recognizable recurring character in Martina Hill's Knallerfrauen, the "Bier-Mama" ("Beer-Mummy"), as she is dubbed on the programme's Facebook page. In the sketches around this character, the blonde, slim, and attractive Hill always appears with dark sunglasses and a can of beer in hand. These physical accessories, complemented by her monotone intonation and disinterested posture, are enough to signal that this woman is the sort of asocial mother that has been sensationalized in recent years through reality television shows such as Erziehungsalarm ("Childcare Alert," Sat1, 2012), Mission Familie ("Mission Family," Sat1, 2012), Mütter-am-Limit ("Mothers on the Edge," Sat1, 2013), Alleinerziehend - ein 24-Stunden-Job ("Single-Parent-the 24/7 Job," RTL, 2015), and Teenie-Mütter: Wenn Kinder Kinder kriegen ("Teen-Moms: When Children have Children," RTL, 2013-2015). The cult comedy figure "Cindy aus Marzahn" ("Cindy from Marzahn"), the stage persona of Ilka Bessin, is perhaps the most famous embodiment of the social type stigmatized by these programmes. "Cindy aus Marzahn" appears on stage clad in a hot-pink velour tracksuit to regale audiences with tales of a life on social benefits. Her excess weight (not to mention her peroxide hair and garish make-up) is a visual cue for the lack of self-control and self-discipline attributed to her by middle-class society. 
Similar to Bessin, who uses her own experience of unemployment to humanize a stereotype, and shed light on the problems faced by the disenfranchised, Martina Hill plays with the stigma surrounding supposedly irresponsible mothers. One of the more controversial sketches from season three shows the "Bier-Mama" smoking in a car, with the window closed. As the vehicle fills with smoke, her young son asks if they can open the window, to which she replies: "It's bloody cold outside. Do you want us to catch our death?" On the Facebook page for Knallerfrauen, sketches involving this character frequently receive the most "likes" and comments. While some proclaim the sketches to be "simply epic" (Alexandra Hellwig 2015) other posters take offence, having read them at face value. They leave comments such as, "is it not enough that such mothers and fathers exist in reality, do we really have to support them on television!!!" (Adrian Bitterli 2015) or, "making sketches at the expense of children, just to get a laugh, is simply tasteless" (Christin Rammelt 2015). Such emotional reactions to the "Bier-Mama" disclose the social dimension of comedy, which is inextricable from wider cultural discourses ordaining which values are "too precious and too precarious to be exposed to challenge" (Mary Douglas 1986, 366).

The "Bier-Mama" sketches reveal the foundations of such regulatory discourses by complicating a stereotype. In spite of certain external and behavioural markers suggesting that she must be a "bad mother," Hill's character is only ever seen with her child and outside of the home, at the theme park, on the beach, or playing table tennis in the park. He is polite, well behaved, and well dressed, and although she slurs and sways, she is attentive in her own way. She engages in conversation with him (even if she sometimes tells lies) and she goes on a rollercoaster with him over and over again (even though it makes her vomit). She even uses her empty beer cans to construct a game for him when he is ill and bored. Her actions hardly constitute the "intensive mothering" that distinguishes the "good mother"; indeed, Hill's character repeatedly puts her own needs (primarily for alcohol) first. The "BierMama" is, then, a wholly ambivalent figure, as this very moniker suggests. In popular culture, celebrated mothers tend to be referred to using diminutives (the Supermom/"Super-Mutti" or the celebrimon/"Promi-Mama") while the term "mother" is often reserved for negative maternal stereotypes (the welfare mother/"asoziale Mutter" or the working mother/"Rabenmutter"). What is more, Hill and her writers complicate the assumption that certain lifestyles automatically result in damaging parenting. The fact that the "Bier-Mama" is distinguished from the more middle-class figures depicted in Knallerfrauen only by her minimal costume and subtle affectations also implies a refusal to conform to a social discourse that demonizes and stigmatizes individuals based on superficial class differences. In comparison to Ladykracher, costume does not play an important role in setting up the sketches in Knallerfrauen. Hill does not hide behind character masks; she orchestrates her jokes from a position of proximity and similarity rather than difference and implied superiority. This approach characterized the alternative comedy that gained ground in the 1980s and has shaped the comedy scene ever since (Deborah Finding 2010, 128).

This aesthetic also means that, on a visual level at least, the "Bier-Mama" is not overly differentiated from the other mothers depicted in Knallerfrauen, from the "Turbo-Mütter" to ordinary but overwhelmed mothers and those who act out and are mean to their children. A single episode of Knallerfrauen thus brings together figures that do not usually appear side-by-side in popular culture: the "new mom" and the "bad" welfare mom (not to mention the frequently overlooked "average" mother). The juxtaposition of maternal stereotypes is necessary, Douglas and Michaels $(2004,181)$ argue, because it exposes the fact that these 
stereotypes are made to figure non-existent absolutes when they are, in fact, stages on the same experiential continuum.

If, in Ladykracher, Engelke exploits the humour of situations in which mothers do not act the way we expect of them, then Hill's configuration of similar scenarios also suggests why they might do so. Hill has repeatedly stated that her comedy takes as its starting point the pressures faced by women in their day-to-day lives. A repeated target of her satire is the cult of "new momism" - a term referring to the way in which intensive mothering is glamorized in today's society. This discourse emphasizes mothers' twenty-four-seven responsibility for their children, while also suggesting that only motherhood will bring women true fulfilment. It also makes consumption integral to fulfilled motherhood and successful mothering, selling all manner of devices and potions as solutions to the anxieties and difficulties of mothering in the twenty-first century, while also insisting that a mother must provide not only psychologically but economically for the well-being of her child (Angela McRobbie 2006; Shari Turner 1994, 296). Expenditure thus becomes a visible measure of maternal love (Douglas and Michaels 2004, 135).

The related ideology of maternal glamour seeks to make motherhood more desirable. Unlike fashion trends, however, Lang (2005) warns, children cannot be swapped, discarded, or hidden in the back of the wardrobe at the end of the season: mothering is a life-long commitment. Hill strikes a similar note in her sketches about women for whom babies are merely fashion accessories. We see, for example, two mothers who stop to coo not at each other's babies but at the blankets in which they are wrapped. At the end of the sketch, their materialism leads the mothers to swap blankets and babies. Hill thus wryly exposes the material rather than maternal desire that underpins the German discourse of the "TurboMutter." In another sketch on a related theme, two mothers have a pedagogical discussion about how best to prepare their little ones for future careers in the competitive, global market. One insists on the benefits of teaching children languages early, telling her friend that she only ever speaks English to her daughter, who enters the room at that moment. They begin a conversation in absolute gobbledegook, an overly literal translation of German into English.

Daughter: Can I to Julia?

Mother: Mama have you said that you first your homework make must.

Here, Hill satirizes the cultural mantra that the mother is always best placed to manage and execute all aspects of her child's upbringing, a standard that stigmatizes those forced to delegate. Making supermom stereotypes the object of satire fits in with Hill's maternal comedy more generally, which illuminates the pressures placed on women to live up to absurd social standards. Indeed, many of Hill's sketches revolve around mothers who "fail" in some way - to uphold a cheery façade or to juggle childcare, work, and personal life, for instance. Some find inventive (if mean) ways to stop their children from causing mayhem while they work. Others go to great lengths to try and hide the fact that they get stuck when helping their children with homework. Some sketches are more absurd, showing a mother who arrives at the railway station only to realize that she has brought the rubbish with her and deposited her child by the garbage bins. Many of these skits are funny precisely because they exaggerate the conceivable. Hill argues that the mothers in her sketches are not mean or neglectful because they are inherently bad people but simply because they are overwhelmed. Hill explains that this emotion is the "trigger for their somewhat unconventional 
reactions" (Henning Hönicke 2014). In these situations, humour naturalizes ideas such as maternal forgetfulness and frustration that all too quickly become hallmarks of the demonic "bad mother" in popular culture.

Reflecting on her interaction with viewers, Hill muses, "the things I say in these moments strikes a chord with people. Secretly some mothers might also want to do the things I do" (Hönicke 2014). In this manner, comedians like Hill function as what Lawrence Mintz (1985, 75) calls a "comic spokesperson." Rather than reinforce stigma about mothers who fail to live up to society's high standards, Hill's humour provides an outlet for taboo social feelings. Prominent humour theorists, including Sigmund Freud and Mikhail Bakhtin, believe that laughter provides temporary relief from the force of the superego, that is to say, from the regulatory power of social mores. Comedy unlocks the gate to what Glyn White and John Mundy $(2013,14)$ call a "cognitive playground where anything goes," where we can revel in thoughts, attitudes, and behaviours that normally would be taboo-and that might in fact have serious repercussions. The sketch, an ephemeral form, offers "comic insulation" from real-world consequences (Jerry Palmer 1987, 45). After all, in ordinary life, a mother cannot simply refuse to perform her maternal duty of care, hence the ease with which non-traditional maternal practices become inscribed in the cultural imagination in moral terms (Mielle Chandler 2007, 274; Emily Jeremiah 2003, 42). Liberated from traditional narrative rules, however, sketch comedy shifts the emphasis to the mother's actions, rather than their consequences for her child, leading us to question the ethics of a cultural institution ("motherhood") that causes women to repress their own anxieties, frustrations, and emotional needs.

The most politically interesting of Hill's sketches depict those mothers who do not keep their tensions bottled up. When a young daughter comes home from school, enthusing about her day, her mother nonchalantly responds:

Enjoy it, it'll be over before you know it. It happens so quickly. How old are you now, eight? Then you've only really got a few months before it starts [...], you know, the great big shitstorm. Let's see, first of all you'll get spots and an inferiority complex [...]. And school, well sweetie, you won't be doing this kid's stuff for ever. By the second year of high school, at the latest, you won't be able to keep up anymore, it'll be hell. And then you'll have the boys to deal with who promise you eternal love just so that they can grope around under your T-Shirt. [...] And then along will come the next bastard, who'll knock you up, and you'll marry him and your career's buggered before you've even gotten started. And then, to be honest, it only gets worse ...

Here Hill embodies what Douglas and Michaels $(2004,74)$ dub the "mouthy mother" who emerged in the wake of second-wave feminism and refused to keep quiet about her negative feelings about life as a mother. Mouthy mothers are outlaws who challenge the myth that mothering is "an endlessly renewing, transcendent, ever-joyful experience" $(2004,220)$. In so doing, they make visible a form of counter-discourse, giving women permission to shake off the yoke of official maternal dogma. Hill's sketches, in particular, shed light on the ambivalent reality of mothering. The taboo nature of this undertaking was made obvious by a recent furore in the German print and social media about women who "regret motherhood" (Anna Sauerbrey 2015). This debate was triggered by a qualitative study about Israeli mothers who admitted that, if they could turn back time, they would choose not to have children (Orna Donath 2015). The controversy developed as German women came forward-in blogs, tweets, and newspaper commentaries-to explain their sympathy with this view and describe how overwhelmed they were by the experience of mothering. Frequently, however, pundits from across the political 
spectrum dismissed their complaints as trivial, self-indulgent, and selfish. As author Antonia Baum (2015) mused, such responses reveal the German myth of motherhood to be sacrosanct; "after all, at the end of the day we're talking about the survival of the nation and the final thing (the inviolable mother image) that this country is allowed to believe in."

\section{The maternal politics of sketch comedy}

Through their focus on the day-to-day realities of mothering, Engelke and Hill pierce such sacralising myths about motherhood. Their sketches carve out a comic counter-discourse for sentiments that evade straight expression. In other words, Engelke and Hill use humour to cut through the "official seriousness" of contemporary maternal culture. Mikhail Bakhtin coined this term in Rabelais and his World (1968 [1965]), in which he discusses humour and laughter in relation to the carnival spirit. Bakhtin defines the carnivalesque as counterhegemonic, characterized by humour and the grotesque; it frees "human consciousness, thought, and imagination for new potentialities" by suspending all hierarchies, norms, and prohibitions (Bakhtin 1968, 49). In the grotesque imagery of carnival, the sacred is degraded while the debased is elevated. This comic process aptly describes the process through which Engelke and Hill pierce maternal myths. Where the maternal is concerned, however, traditional comic theory and practice has been blind to the political potential of such profanation. It is worth considering this tradition in more detail in order to illuminate the paradoxical attitudes towards motherhood that are so deeply embedded in Western culture that they are deemed outside the remit of the comic. This in turn will accentuate the doubly subversive nature of the maternal sketches by Engelke and Hill.

Explaining their sense that humour is (or, should be) a male preserve, male pundits have suggested that to laugh at a woman would be tantamount to laughing at and degrading the wonder of motherhood. For example, American comedian Jerry Lewis explains that he is uncomfortable with aggressive and crude women's comedy because: "I have a problem with the lady up there that's going to give birth to a child - which is a miracle" (The Associated Press 2014). Respected psychoanalyst Martin Grotjahn $(1966,100)$ suggested along similar lines that "it is difficult to distort the relationship to the mother in a way that makes us laugh." Given such claims, it is perhaps unsurprising that the figure of the mother has been "largely absent" as a comic agent in film comedy-unless she is degraded as an obstacle to the escapades of the male hero (Lucy Fischer 1996, 115).

Leading theories of comedy are similarly ambivalent about motherhood. According to Fischer $(1996,14)$, the absence of women, and particularly mothers, in theoretical discussions of comedy is "particularly bizarre" given the origins of the genre in the female fertility rites of ancient Greece. And yet when we look more closely at this tradition, it is precisely the symbolic role of women in this tradition that goes some way towards explaining the ambivalence towards actual motherhood in comedy. Women's participation in ancient comic rituals is hardly expunged from the theoretical canon. This tradition clearly informs Northrop Frye's Anatomy of Criticism (2000 [1948]). When Frye describes the organic, "archetypal" patterns that structure conventional literary genres, he associates comedy, as mythos or generic plot, with spring, that is with renewal, rebirth, and triumph. For Frye $(2000,183)$, this archetypal association elucidates the heroine's central role in the resolution of Shakespearean comedy which subjects her to a cycle of degradation and ultimate renewal. The ritualistic prehistory 
of comedy also underpins Susanne K. Langer's Bergsonian understanding of the comic form as an expression of human vitality, that is, as a reflection of natural rhythms. Susanne K. Langer $(1953,331)$ reminds us that the word comedy derives from fertility rites associated with the Greek God Comus, "a symbol of perpetual rebirth, eternal life." Langer's codification of rebirth and comedy as masculine exemplifies the slippage that frequently occurs between the maternal procreative and the masculine generative in theories of the comic (see also Jerry Palmer 1994, 32; Andrew Stott 2014, 4).

A similar elision of the maternal is found in Bakhtin. The carnivalesque body is described as one that both "fecundates and is fecundated, that gives birth and is born, devours and is devoured, drinks, defecates, is sick, and is dying" $(1968,319)$. At least on the level of metaphor, then, the celebrated "material body principle" is decidedly maternal. Bakhtin's account of carnival revellers and jokers is androcentric, however. It banishes women (as mothers) to the realm of the imaginary. Bakhtin ambivalently describes how the grotesque image of the body is essentially"two bodies in one: the one giving birth and dying, the other conceived, generated, and born. This is the pregnant and begetting body, or at least a body ready for conception and fertilization" (26). The envelopment of the passive and procreative maternal body by the reborn subject is more explicitly evoked in a later description of the grotesque image of birth as "the body that is born and at the same time shows a glimpse of the departing one" (408), where the body that departs is implicitly maternal.

As Ruth Ginsburg $(1993,168)$ elaborates, Bakhtin's focus is on "the body of the human race that is always being born; it does not give birth" - an act that distinguishes women. The material body of Bakhtin's theory is universal, however, as is the spiritual rebirth facilitated by the carnivalesque, which thus depends on the recodification of the maternal and biological in terms of the "historic, progressing body of mankind" (367). This is a figurative not a literal birth. Since Bakhtin's interest lies more in the historical and the cosmic rather than the mortal and earth-bound, it is not surprising that he dismisses as "feeble" the seventeenth-century tradition of grotesque realism and especially the then fashionable literary caquets or "cackles," particularly the "Caquet de l'accouchée" "“Cackle of the Confined Woman," 1622), which recounts the frank conversation of women at the bedside of a woman recovering from childbirth. Here, Bakhtin contends, "the popular frankness of the marketplace with its grotesque ambivalent lower stratum is replaced by chamber intimacies of private life, heard from behind a curtain" $(1968,105)$. The existential and political dimensions of the grotesque thus apparently give way to private and trivial concerns.

Such condescension about the social value of women's talk and humour recall more recent arguments (in Germany and across the Western world) about the shallowness of female comedy, namely the alleged incapacity of comediennes to transcend the personal (Daniel Haas 2008; Reinhard Mohr 2008). A striking example of this view was expressed by American pundit Christopher Hitchens (2007) in a polemic article on women and humour. Hitchens controversially suggested that, unlike men, women fail to see humour in the calamities of the everyday - and that the "sheer tedium" of their day-to-day experience simply does not generate funny stories. Take a mother talking about her baby as a case in point: "Is there anything so utterly lacking in humour?" And how often, he muses, do you encounter mothers joking about their children? We can easily question the veracity and critical rigour of such statements. Mercilee Jenkins (1985), for example, showed that humour among women frequently revolves around unrealistic maternal norms and their experiences of mothering. Hitchens' article is enlightening, however, precisely because of the cultural 
assumptions that it makes explicit. Curiously, Hitchens cites motherhood as one of the reasons why women do not need to be, and therefore are not, funny. Motherhood allegedly blinds women to the hilarity of bodily functions and "imbues them with the kind of seriousness and solemnity at which men can only goggle," giving women an "unchallengeable authority." If men have used humour to make up for their deficiencies and protect themselves from attack, he argues, echoing Freud (1905), then women (naturally superior) simply need not avail themselves of the comic.

Such paradoxical attitudes to women as mothers suffuse maternal culture in the West, which exalts motherhood as an institution while denigrating the actual work of mothering. Susan Maushart $(1997,5)$ refers to this paradox and the power dynamics it disguises as the "mask of motherhood."This mask "conceals from the world and from ourselves the momentousness of our common undertaking. The mask is what mutes our rage into murmurs and softens our sorrow into resignation." Belying the actual experience of mothering, the cultural fetish of motherhood places pressure on women first to become mothers, then to live up to impossible ideals, and finally to maintain the mask of motherhood at the risk of their emotional health. The mask of motherhood naturalizes maternity and maternal self-sufficiency by whitewashing the political contours of motherhood.

Through their maternal sketches, Anke Engelke and Martina Hill excoriate the mask of motherhood. The comic sketch (typically less than two minutes long) is a privileged vehicle for presenting the intertwined private and political dimensions of maternal subjectivity. The form adopts what we might call an "anecdotal approach" to motherhood, allowing us to understand the ways in which maternal subjectivity is "a transitory state, revealed through numerous 'hiccups,' or unaccommodations in the daily lived experience of mothering," as Lisa Baraitser $(2009,10)$ has suggested in a different context. Following Jane Gallop's approach in Anecdotal Theory, Baraitser seeks to bring "anecdote" and "theory" into alignment in a manner that challenges the conventional hierarchy of the grand over the humorous, the overarching over the trivial, and the universal over the specific. Like the anecdote, the sketch can be seen to capture "something of the indigestibility of maternal experience" (11). Both discursive forms illuminate the "secret histories" that rarely find continuous narrative expression, submerged as they are by the incessant cycle of maternal work (12). Frequently, however, these indigestible experiences "resurface as anecdote-often in the form of funny stories we tell each other about silly or charming things our children did or said" (13). Such anecdotes may form the basis of a maternal humour, feminist critics have suggested, allowing women to find recognition and support amongst like-minded individuals (Mary Crawford 2003, 1421; see also Coates 1996; Mary Crawford and Diane Gressley 1991). The politics of sketch comedy involve transferring such anecdotes into the public sphere, using exaggeration to contest idealized conceptions of motherhood that ignore and trivialize the realities of mothering. It is precisely because traditional comedy over and again re-inscribes this paradox in its practice that Engelke and Hill's sketches are uniquely placed to generate insight, by ensuring that the way they present their view of maternal culture is as shocking as what they say about it.

\section{Note}

1. All translations from the German are mine unless otherwise stated. 


\section{Disclosure statement}

No potential conflict of interest was reported by the author.

\section{Funding}

This work was supported by an Irish Research Council Starter Research Project Grant (strand RPG20131) awarded to Valerie Heffernan as Principal Investigator.

\section{Notes on contributor}

Katherine Stone completed a PhD on "Gender and German Memory Cultures: Representations of National Socialism in Post-1945 Women's Writing" at the University of Cambridge in 2014. She is currently a Government of Ireland Postdoctoral Research Fellow at Maynooth University, working on the representation of sexual violence in German memory culture. Email: Katie.Stone@nuim.ie

\section{References}

Alleinerziehend-ein 24-Stunden-Job ["Single-Parent—the 24, 7 Job"]. 2015. Television Series. Germany: RTL.

Bakhtin, Mikhail. 1968. Rabelais and His World. Translated by Helene Iswolsky. Cambridge, MA: MIT Press. Baraitser, Lisa. 2009. Maternal Encounters: The Ethics of Interruption. London: Routledge.

Baum, Antonia. 2015. "Die Mutterschaft ist heilig." Frankfurter Allgemeine Sonntagszeitung, April 19, 16th edition.

Beck-Gernsheim, Elisabeth. 2001. "Declining Birth Rates and the Wish to Have Children." In Individualization: Institutionalized Individualism and Its Social and Political Consequences, edited by Patrick Camiller, 119-128. London: Sage.

Bergson, Henri. 1921. Laughter: An Essay on the Meaning of the Comic. Edited by Cloudesley Brereton and Fred Rothwell. New York: The Macmillan Company.

Bitterli, Adrian. 2015. “Reicht Es Nicht Das Es in Der Realität Auch Solche Mütter Und Väter Gibt Muss Man Das Am Tv Noch Unterstützen Schlimm!!!!!"February 14. Accessed April 28, 2016. https://www. facebook.com/knallerfrauen.sat1/videos/951102378248081/

BRAINPOOL. 2003. “Ladykracher geht in die dritte Runde." Accessed April 5, 2015. http://www.brainpool. de/Presse/2003/September/Ladykracher-geht-in-die-dritte-Runde

Burkart, Günter. 2006. "Zaudernde Männer, Zweifelnde Frauen, Zögernde Paaren: Wer Ist Schuld an Der Kinderlosigkeit." In Der Demographische Wandel: Chancen Für Die Neuordnung Der Geschlechterverhältnisse, edited by Peter A. Berger and Heike Kahlert, 111-136. Frankfurt am Main: Campus.

Chandler, Mielle. 2007. "Emancipated Subjectivities and the Subjugation of Mothering Practices." In Maternal Theory: Essential Readings, edited by Andrea O'Reilly, 529-541. Toronto: Demeter Press.

Coates, Jennifer. 1996. Women Talk: Conversation between Women Friends. Oxford: Blackwell.

Crawford, Mary. 2003. "Gender and Humor in Social Context." Journal of Pragmatics 35 (9): 1413-1430.

Crawford, Mary, and Diane Gressley. 1991. "Creativity, Caring, and Context:Women's and Men's Accounts of Humor Preferences and Practices." Psychology of Women Quarterly 15 (2): 217-231.

Die Wochenshow ["The Weekly Show"]. 1996-2002. Television Series. Germany: Sat1.

Donath, Orna. 2015. "Regretting Motherhood: A Sociopolitical Analysis." Signs 40 (2): 343-367.

Douglas, Mary. 1986. "The Social Control of Cognition: Some Factors in Joke Perception." MAN 3 (3): 361-376.

Douglas, Susan, and Meredith Michaels. 2004. The Mommy Myth: The Idealization of Motherhood and How It Has Undermined All Women. New York: Free Press.

Erziehungsalarm ["Childcare Alert"]. 2012. Television Series. Germany: Sat1.

Fabio, Udo di. 2005. Die Kultur der Freiheit [The Culture of Freedom]. Munich: C.H. Beck. 
Finding, Deborah. 2010. "'The Only Feminist Critic in the Village?': Figuring Gender and Sexuality in Little Britain." In Reading Little Britain: Comedy Matters on Contemporary Television, edited by Sharon Lockyer, 127-146. London: I.B. Tauris.

Finney, Gail. 1994. "Introduction: Unity in Difference?" In Look Who's Laughing: Gender and Comedy, edited by Gail Finney, 1-13. Langhorne: Gordon and Breach.

Fischer, Lucy. 1996. Cinematernity: Film, Motherhood, Genre. Princeton, NJ: Princeton University Press. Fiske, John. 2009. Television Culture. London: Routledge.

Frankfurter Allgemeine Zeitung. 2005. "FAZ.NET-Spezial Die demographische Zeitbombe." April 28. Accessed April 28, 2016. http://www.faz.net/aktuell/wirtschaft/faz-net-spezial-die-demographischezeitbombe-1120257.html

Freud, Sigmund. 1905. Der Witz und seine Beziehung zum Unbewußten. Leipzig and Vienna: Franz Deuticke.

Frye, Northrop. 2000. Anatomy of Criticism. Princeton, NJ: Princeton University Press.

Ginsburg, Ruth. 1993. "The Pregnant Text: Bakhtin's Ur-Chronotope: The Womb." In Bakhtin: Carnival and Other Subject, edited by David Shepherd, 165-176. Amsterdam: Rodopi.

Grotjahn, Martin. 1966. Beyond Laughter: Humor and the Subconscious. New York: McGraw-Hill.

Haas, Daniel. 2008. “Comedy: Pointen im Säurebad." Der Spiegel, November 3. Accessed April 28, 2016. http://www.spiegel.de/spiegel/print/d-61822129.html

Heffernan, Valerie. 2014. "Mediating the Mommy Wars in Contemporary Germany." In Stay-at-Home Mothers: Dialogues and Debates, edited by Elizabeth Reid Boyd and Gayle Letherby, 129-139. Bradford, ON: Demeter.

Hellwig, Alexandra. 2015.“Einfach Nur Geil!!!!”October 7. Accessed April 28, 2016. https://www.facebook. com/knallerfrauen.sat1/videos/vb.745463695478618/951102378248081/?type=2\&theater

Herman, Eva. 2006. Das Eva-Prinzip: Für Eine Neue Weiblichkeit. Munich: Pendo.

Heute-Show ["Today Show"]. 2009-present. Television Series. Germany: ZDF.

Hitchens, Christopher. 2007. "Why Women Aren't Funny." Vanity Fair, January.

Hönicke, Henning. 2014. "Martina Hill über Feminismus, Humor und Frauen:'Ich bin keine Feministin."” Brigitte.de, July 23.

Jenkins, Mercilee. 1985. "What's So Funny? Joking Among Women."In The Proceedings of the First Berkeley Women and Language Conference, edited by Noelle Caskey, Sue Bremner and Birch Moonwomon, 135-151. Berkeley: Berkeley Women and Language Group.

Jeremiah, Emily. 2003. Troubling Maternity: Mothering, Agency, and Ethics in Women's Writing in German of the 1970s and 1980s. London: MHRA.

Knallerfrauen ["Women with a Bang”]. 2011-2014. Television Series. Seasons 1-4. Germany: Sat1.

Knop, Karin. 2007. Comedy in Serie: medienwissenschaftliche Perspektiven auf ein TV-Format. Bielefeld: Transcript.

Kotthoff, Helga. 2004. "Geschlechterverhältnisse in der Scherzkommunikation: Althergebrachtes und neue Trends in Alltags- und Fernsehkomik." In Gender Studies: interdisziplinäre Ansichten, edited by Helga Epp, 1:15-51. Schriftenreihe der Frauenbeauftragten der Pädagogischen Hochschule Freiburg 2. Freiburg im Bresgau: Pädagogische Hochschule Freiburg.

Kröhnert, Steffen, and Reiner Klingholz. 2008. “Emanzipation oder Kindergeld? Was die neue Familienpolitik Deutschlands von anderen europäischen Ländern gelernt hat." Berlin: Berlin-Institut für Bevölkerung und Entwicklung. Accessed April 28, 2016. http://www.ssoar.info/ssoar/handle/ document $/ 32173$

Ladykracher ["Cracking Ladies"]. 2001-2013. Television Series. Seasons 1-8. Germany: Sat1.

Lang, Susanne. 2005. "Ich bin jetzt auch Mutter!" TAZ, April 22.

Langer, Susanne K. 1953. Feeling and Form: A Theory of Art Developed from Philosophy in a New Key. New York: Scribner.

Little, Judy. 1983. Comedy and the Woman Writer: Woolf, Spark, and Feminism. Lincoln, NE: University of Nebraska Press.

Maushart, Susan. 1997. The Mask of Motherhood: How Mothering Changes Everything and Why We Pretend It Doesn't. Milsons Point, NSW: Random House Australia.

McRobbie, Angela. 2006. "Yummy Mummies Leave a Bad Taste for Young Women." The Guardian, February 3. Accessed April 28, 2016. http://www.theguardian.com/world/2006/mar/02/gender. comment 
McRobbie, Angela. 2013. “Feminism, the Family and the New'Mediated'Maternalism." New Formations: A Journal of Culture/Theory/Politics 80 (80): 119-137.

Medhurst, Andy. 2007. A National Joke: Popular Comedy and English Cultural Identities. Abingdon: Routledge.

Mintz, Lawrence. 1985. "Standup Comedy as Social and Cultural Mediation." American Quarterly 37 (1): 71-80.

Mission Familie ["Mission Family"]. 2012. Television Series. Germany: Sat1.

Mohr, Reinhard. 2008. "Frauen und Humor: Jeder Witz braucht einen Bart!" Spiegel Online, November 7. Accessed April 28, 2016. http://www.spiegel.de/kultur/gesellschaft/frauen-und-humor-jeder-witzbraucht-einen-bart-a-587983.html

Mütter-am-Limit ["Mothers on the Edge"]. 2013. Television Series. Germany: Sat1.

Palmer, Jerry. 1987. The Logic of the Absurd: On Film and Television Comedy. London: BFI Publishing.

Palmer, Jerry. 1994. Taking Humour Seriously. London: Routledge.

Parker, Rozsika. 1997. "The Production and Purpose of Maternal Ambivalence." In Mothering and Ambivalence, edited by Wendy Holloway and Brid Featherstone, 17-35. London: Routledge.

Presseportal. 2014. “Martina Hill hoch drei, mal zwei!”February 2. presseportal.de. Accessed April 5, 2015. http://www.presseportal.de/pm/6708/2659790/martina-hill-hoch-drei-mal-zwei-die-dritte-staffelknallerfrauen-ab-21-maerz-in-sat-1

Rammelt, Christin. 2015. "Ich Finde Sketche Auf Kosten von Kindern Nur Um Einen Lacher Zu Bekommen Einfach Nur Geschmacklos! !!" February 14. Accessed April 28, 2016. https://www.facebook.com/ knallerfrauen.sat1/videos/951102378248081/

SAT1. 2011. “Anke Engelke im Interview," December 21. Accessed April 28, 2016. http://www.sat1.de/ tv/ladykracher/interviews/anke-engelke-im-interview

Sauerbrey, Anna. 2015. "Wie eine kleine Studie zum Medienhype wurde." Der Tagesspiegel, April 26. Accessed April 28, 2016. http://www.tagesspiegel.de/themen/causa/regrettingmotherhood-wieeine-kleine-studie-zum-medienhype-wurde/11687622.html

Schader, Peer. 2012. “'Knallerfrauen' mit Martina Hill: Sie macht ja nur Spaß." Berliner Zeitung, March 2. Accessed April 28, 2016. http://www.berliner-zeitung.de/medien/-knallerfrauen-mit-martina-hillsie-macht-ja-nur-spass, 10809188,11562352.html

Schießl, Michaela. 2015.“Humor Lecker Mädchen.”Der Spiegel, March 21. Accessed April 28, 2016. http:// www.spiegel.de/spiegel/print/d-132701114.html

Schirrmacher, Frank. 2004. Das Methusalem-Komplott [The Methuselah Complot]. Munich: Blessing.

Schumacher, Gerlinde, and Daniela Hammer. 2000. "Humorsendungen im Fernsehen: Angebot, Nutzung, Anforderungen." Media Perspektiven 4 (12): 562-573.

Smack the Pony. 1999-2003. Television Series. Seasons 1-4. UK: Channel 4.

Stott, Andrew. 2014. Comedy. London: Routledge.

Switch Reloaded ["Switch Reloaded"]. 2007-2012. Television Series. Seasons 1-6. Germany: ProSieben. Teenie-Mütter: Wenn Kinder Kinder kriegen ["Teen-Moms: When Children have Children"]. 2013-2015. Television Series. Germany: RTL.

The Associated Press. 2014. "Jerry Lewis: Women Are Funny, But Not When Crude." Hollywood Reporter, April 12. Accessed April 28, 2016. http://www.hollywoodreporter.com/news/jerry-lewis-womenare-funny-695667

Turner, Shari. 1994. The Myths of Motherhood: How Culture Reinvents the Good Mother. New York: Houghton Mifflin.

Vous les Femmes ["WOMEN!"]. 2007-2010. Television Series. Seasons 1-4. France: CALT.

Wantoch, Katharina. 2015. "'Ladykracher' Anke Engelke: 'Ich bin die Erste, die Witze auf Kosten von Frauen macht."' BRIGITTE. Accessed April 5, 2015. http://www.brigitte.de/kultur/lifestyle/ankeengelke-ladykracher-1040516/

White, Glyn, and John Mundy. 2013. Laughing Matters: Understanding Film, Television and Radio Comedy. Manchester: Manchester University Press.

Williams, Raymond. 1977. Marxism and Literature. Oxford: Oxford University Press. 